\title{
ROLE OF 3PL OPERATORS IN IMPROVEMENT IN COMPETITIVE ADVANTAGE OF COMPANIES WITH THE EXAMPLE OF IKEA HANIM POLSKA
}

\author{
Joanna Nowakowska - Grunt, Phd,jng@zim.pcz.pl \\ Częstochowa University of Technology, Management Faculty
}

\begin{abstract}
Recent years have seen a growing importance of third-part logistics (3PL). The reasons for this include increased the role of logistics outsourcing. Most of companies begins cooperation with logistics services provider. In this paper presents relations between Ikea Hanim Polska and FM Logistics
\end{abstract}

It is difficult to find a uniform, concise definition of logistics operator. The subject literature, as well as economic practice indicate wide range and divergence of services which might be the matter of logistics operator activities. Legal status, size and other factors which characterize companies also differs in businesses which in current circumstances take up responsibility for particular logistics activities, termed 'logistics operators'. The companies which operate in Polish market offer a variety of transport-forwarding-logistics services, such as:

- logistics companies (logistics operators)

- transport companies

- transport and forwarding companies

- personal transport companies,

- courier companies,

- storage companies,

- logistics consulting companies,

- mail operators,

- railway operators,

- logistics centres,

- marine and inland ports,

These companies are of varied potential, with different level of development of the transport and warehouse infrastructure, different experience and level of services. However, any company which provides transport, warehousing, inventory management or packing services is generally recognised as logistics operator.

The question arises of where the border between transport, forwarding and logistics companies is. Transport and forwarding companies provide services which are only a part of a complex supply chain. They might be both direct service provider for companies or subcontractor for the logistics operator, who integrates individual elements throughout the supply chain.

Logistics operator is an entity which organizes, activates and supervises flow of goods and information, while working to order for an entity for existence of whom a logistics stream is necessary. The scope of duties and areas of operator activities depend on the decision of the ordering party. Relationships between ordering company and logistics operator are becoming so advanced that the concepts of superiority and duty fade away, while cooperation or partnership appears ${ }^{1}$. The customers expect complex logistics services in one place, so called one-stop shopping

\footnotetext{
${ }^{1}$ Grabara J., Jahnatek L., "Poprawa konkurencyjności przedsiębiorstwa dzięki nowoczesnym rozwiązaniom logistyki odwrotnej", Zarządzanie w przedsiębiorstwie , cz.2, Wyd. Politechniki Częstochowskiej, Częstochowa 2007
} 
services, through which they reach optimum in terms of costs, time and comfort. Such cooperation often requires to work out mutual trust between parties, creation of joint IT systems or even creation of interorganizational teams.

Most important arguments which justify rationality of subcontracting in particular parts of logistics processes to logistics operators include:

$>$ lack of specialized staff, equipment and attitude to invest capital in such equipment,

$>$ better use of resources (material, human, financial and informational resources)

$>$ more efficient flow in logistics streams executed by dedicated companies,

$>$ synergy of activities,

$>$ opportunity for the ordering party to focus on their fundamental activities. ${ }^{2}$

The idea of logistics operators' existence in the market is closely related to outsourcing strategies, lean production or lean management. The contracting should be clearly highlighted, where ordering party takes full control over the processes, i.e. clearly defines to the outsourcer how the order should be executed (in detail), as opposed to the contract, where clients focus on determination of the final form of the product which they are willing to purchase. The method to achieve the appropriate results is left up to logistics operator.

The abovementioned situation is what is most common for all logistics solutions today.

The scope of subcontracted services gives opportunity of division of logistics operators into universal and specialized operators.

Specialized operators means entities of a fragmentary activity, which execute a particular part of a logistics process, e.g.:

$>$ transport companies from various branches,

$>$ warehouses,

$>$ packaging and custom packaging companies,

$>$ insurance companies,

$>$ customs organizations,

$>$ cargo companies etc.

Despite the fact that nowadays companies focus on development and wide range of services, the specialization in the market is gaining grounds. This is caused by regulations and laws which define precisely the method of transport and storage for e.g. perishable or hazardous products as well as for spare parts. The range of dedicated services is growing according to the growth in customers' demand and in line with implementation of specific (usually centrally planned by the companies) solutions for improvement in supply chains. ${ }^{3}$

Courier services are most rapidly developing among specialized logistics services which appear in the market. In Polish market, except for world tycoons (UPS, DHL, TNT) and other huge domestic companies (Stolica, Servisco, Szybka Paczka) there are numerous small and medium size local companies. Courier companies are developing towards extension of range of their services and complex control over logistics processes. Another tendency in development of these companies is informatization of services which enables tracking the route of delivery through SMS texts or WAP viewers, contact with on-line couriers, automation of handling activities and electronic transactions, including payments.

Universal operator in logistics process is the operator whose activities encompass all the activities in domestic and international turnover of material goods, both outside the entity and in its internal structures. Such entities, termed third party logistics (3PL) offer packages of logistics services. A characteristics of logistics packages is compilation of various partial services connected with widely understood transport and storage of goods into an integrated logistics offer which is formed, sold

\footnotetext{
${ }^{2} \mathrm{http}$ ://www.logistykafirm.com/operatorzy polskiego rynku usług logistycznych

${ }^{3}$ http://www.wnp.pl/2318_1.html

Logistyka: I ty możesz zostać operatorem (You Can Be the Operator, Too)
} 
and settled as a unit. Types of partial services within a particular package depend, on the one hand, on customer's demand, and on a range of services offered by a particular company and its readiness to provide other additional services. ${ }^{4}$

The operator's task is to improve, through services provided to production or trade company, logistics services provided to end customer. ${ }^{5}$ In order to improve quality of services, logistics operator employs its international existence in the market, know-how and experience in many markets, ensuring optimization of the whole supply chain. Through such activities they make efforts to overtake business activities with higher value added, which are not core business activities for the client. Operating on an international scale, they derive measurable profits not only on a domestic scale but also globally for the whole company and cooperating businesses.

Enormous value added, from the client's point of view, is time, perceived before as one of the most essential factors of competition. Flow logistics, as a product offered by some logistics operators, is a response to such an expectations. The operators within this system control goods so that they are constantly moving. If a stoppage occurs, it is usually for a short period of time and it is generally connected with adding a value to the goods, as it is in case of cross docking. A cross docking term means such a method of cargo handling in warehouses or in distribution centres where it is not stored but picked and prepared to be delivered to customers. This means certain kind of reloading using warehouse floor area (especially the order picking zones) to form delivery packages according to the recipient's orders. ${ }^{6}$ Professional logistics operators provide for their clients complex services of flow of goods and information, from the creation of the products on a production line to the delivery to final consumer - in right time, with appropriate quality. Best logistics companies offer more and more value added to their clients at ever-decreasing price. A value added in case of services might include the processes of packaging, re-packaging, deliveries of raw materials and packages directly to production lines. The higher value added, the more satisfied a customer is. Integrated logistics services encompass everything what the customer wants. A benefit to the customer is a value added and for the operator the price paid by the customer.

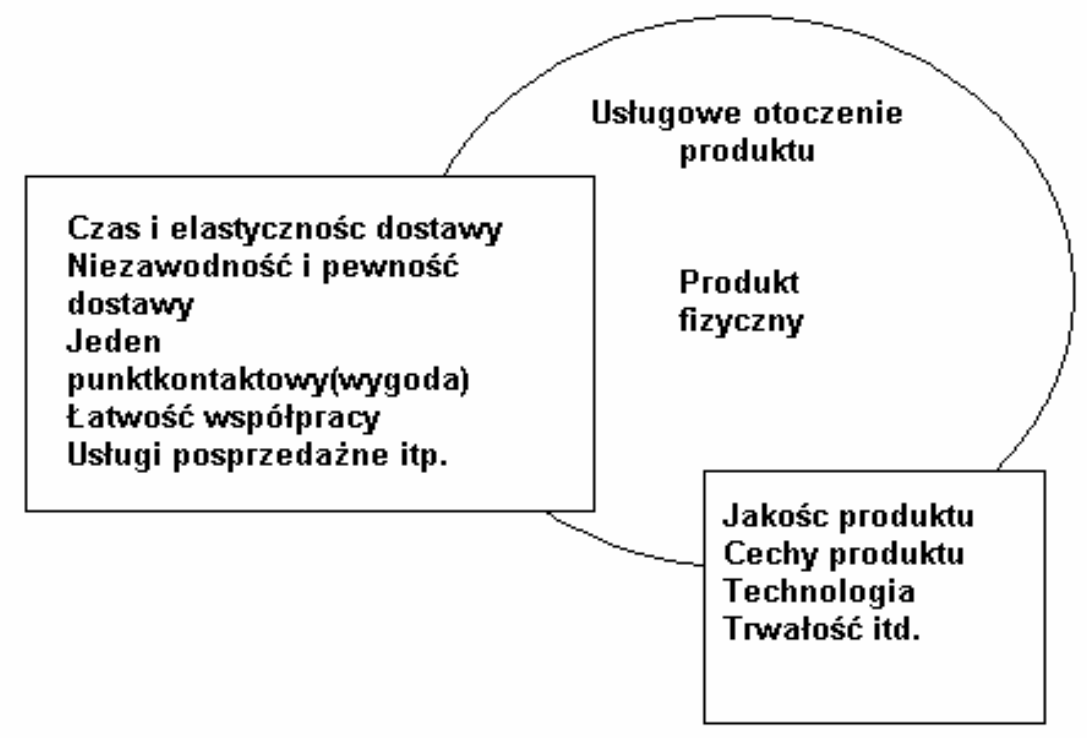

Fig. 5 Logistics services as an element which improves product

\footnotetext{
${ }^{4}$ http://www.logistykafirm.com/sa.php?aid=594\&cat=31\&catname=stl Operatorzy polskiego rynku ustug logistycznych (Operators in Polish Market of Logistics Services)

${ }_{5}^{5}$ M. Ciesielski, Rynek ustug logistycznych (Market of Logistics Services), Difin, Warsaw 2005, p. 66

${ }^{6} \mathrm{http}: / /$ www.logistykafirm.com/sa.php?aid=150\&cat=11\&catname=Teoria
} 
Source: M. Christopher, Logistyka i zarządzanie łańcuchem dostaw (Logistics and supply chain management), PCDL 2000, p.41

Through complex services, costs incurred by the clients decrease while the usability of the services rises. A real future here is a globalization understood as a complex services for the clients, which consists in ensuring services throughout product cycle chain. This means not a door to door sales but much more i.e. one stop shopping.

Swedish IKEA group has been cooperating with 1,600 suppliers from 55 countries which manufacture furniture and household goods to 202 furniture hypermarket in 31 countries worldwide. Every year IKEA distributes 10,000 types of various products with total volume of 16 $\mathrm{m} \mathrm{m}^{3}$, which means that every day thousands of goods leave factories so as to get on shop shelves.

Regional Distribution Centres comprise links between producer and seller i.e. plants which manufacture household goods and IKEA's furniture hypermarkets. There are 27 distribution centres and central warehouses worldwide, including 15 in Europe. One of them is Jarosty. Currently Jarosty Distribution Centre, with total floor area of $100,000 \mathrm{~m} 2$ and capacity of $150,000 \mathrm{~m} 3$, is the biggest such facility in Poland. Value of the whole investment reached $190 \mathrm{~m}$ PLN, which is the biggest investment by IKEA in Europe.

\section{Modern methods of distribution}

Jarosty Distribution Centre employs leading-edge methods of distribution, logistics as well as flow and storage of goods. The warehouse is equipped in modern computerized system of inventory management, ASTRO, which enables precise planning of each events within the warehouse. The orders from IKEA shops are also computer-aided: the system in IKEA shop sends orders to the system in the Distribution Centre and then to the computers installed in forklifts. Additionally, forklifts are equipped in radio terminals which enable connections established with central system of the warehouse. The Distribution Centre has also SILO, one of the most modern Polish half-automated, high storage warehouse. ${ }^{7}$

On 3 August 2003, IKEA opened in Jarosty near Piotrków Trybunalski a Central Warehouse Jarosty II, with usable floor area of 35,000 square metres, 45,000 pallet locations, 7 levels of storage and capacity of goods of 40,000 cubic metres, 22 re-loading car platforms as well as 2 railroad platforms. New facilities are connected with the Central Warehouse Jarosty I established two years before and they make up together a Regional Distribution Centre (Regionalne Centrum Dystrybucji - RCD), providing services, including Polish market, to 15 shops, also in Russia, Czech Republic, Hungary and Slovakia. Jarosty warehouse also ensures order picking for goods produced in Poland to be sold in the UK, USA and Canada. Total floor area of RCD IKEA in Jarosty takes now 100,000 square metres (on the area of $47 \mathrm{ha}$ ), goods capacity of 150,000 cubic metres. Jarosty I warehouse has 6 or 12 levels of storage, 108,000 pallet locations, 45 car platforms and 3 railroad platforms. In total, 250 people are employed by RCD IKEA and the total value of the investment in Jarosty amounted to PLN $190 \mathrm{~m}$. It has been estimated that it is the biggest unit investment by IKEA in the Middle and Eastern Europe. The Centre area is also a location for customs departments.

The investment in Jarosty is not only an example of efficient cooperation of each entities and people involved in creation of the Regional Distribution Centre, but also good contacts with local self-government.

Strengths and weaknesses of cooperation of IKEA, logistics operator of FM Logistics directly or indirectly impact on competitiveness of the company.

The strongest asset of the company, which results from cooperation with FM Logistics, is a possibility to focus efforts on core business. In case of IKEA, this enables concentration in the offer

\footnotetext{
${ }^{7} \mathrm{http}: / /$ www.supermarket.cogdziekupic.pl/archiwum_2005_2
} 
itself i.e. innovation of products, improvement in standards of end consumer service level, modernization of commercial locations, efficient advertising etc.

Undoubtedly, the most favourable impact on position of the company in the market has optimal integration in supply chain and, in consequence, reduction of costs (difference between the costs generated by logistics self-service and costs of using services of specialized logistics operator), improvement in financial conditions of a company. In order for the company to reach desirable competitive position, measured by expected participation in the market and financial standing, it must, first and the foremost, take the competitive advantage in the served segment. This means that its offer must arouse more interest from customers than the offer by customers, which will enable company reaching higher sales while increasing its participation in the market and incomes which improve the financial standing.

Integration of supply chain translates the most into the level of competitive influence of the company. Shortening of lead time and optimal organization of deliveries is essential, which impacts on rise in end consumers' satisfaction along with each saved minute. The company offers their customers more and more value added at lower price - this improves the attractiveness of the offer and makes it more competitive.

According to the abovementioned analysis, the biggest threat to the company's market position is possibility that the competitors will enter into cooperation with service provider which offers more efficient logistics services. Moreover, current market situation of the company depends on the operator's standing and capacity. Any disturbance of these factors would cause the drop in company's efficiency of operation and quality of services and products.

The weakest link of the analysed cooperation is road transport, the only one offered by FM Logistics. Except unquestionable advantages of road transport, such as short lead times, opportunities to provide services in 'door to door' system, competitive prices for the services or flexibility, this solution has several disadvantages. Major disadvantage, perceivable by all the road users, is an intensified traffic congestion. Direct effect of growing traffic congestion is deterioration of existing road infrastructure and reduction in level of road security. Moreover, this form of transport is the most economical and least harmful to the environment (harmful effect of exhaust fumes on natural environment and emission of carbon dioxide). Moreover, entrusting external entities with the logistics services brings uncertainty and risk connected with confidentiality of the information and company's data.

To sum up, the decision of employing operator by IKEA results in possibilities to increase activity in the market, improve quality of own products and increase resources for investments as well as improve the company's position in relation to competitors in line with reduction in costs connected with servicing structures within company.

\section{Bibliography:}

1. Christopher M., Logistyka i zarządzanie łańcuchem dostaw (Logistics and supply chain management), PCDL 2000, p.41

2. Ciesielski M., Rynek ustug logistycznych (Market of Logistics Services), Difin, Warsaw 2005, p. 66

3. Grabara J., Jahnatek L., "Poprawa konkurencyjności przedsiębiorstwa dzięki nowoczesnym rozwiązaniom logistyki odwrotnej", Zarządzanie w przedsiębiorstwie , cz.2, Wyd. Politechniki Częstochowskiej, Częstochowa 2007

4. http://www.logistykafirm.com/operatorzy polskiego rynku usług logistycznych

5. http://www.logistykafirm.com/sa.php?aid=150\&cat=11\&catname=Teoria

6. http://www.logistykafirm.com/sa.php?aid=594\&cat=31\& catname $=$ stl

7. http://www.supermarket.cogdziekupic.pl/archiwum_2005_2, 
8. http://www.wnp.pl/2318 1.html 